\title{
75th Growth Percentile
}

National Cancer Institute

\section{Source}

National Cancer Institute. 75th Growth Percentile. NCI Thesaurus. Code C98265.

An indication that an individual ranks the same or more than 75 percent (top 25 percent)

of the reference population for a given attribute. 